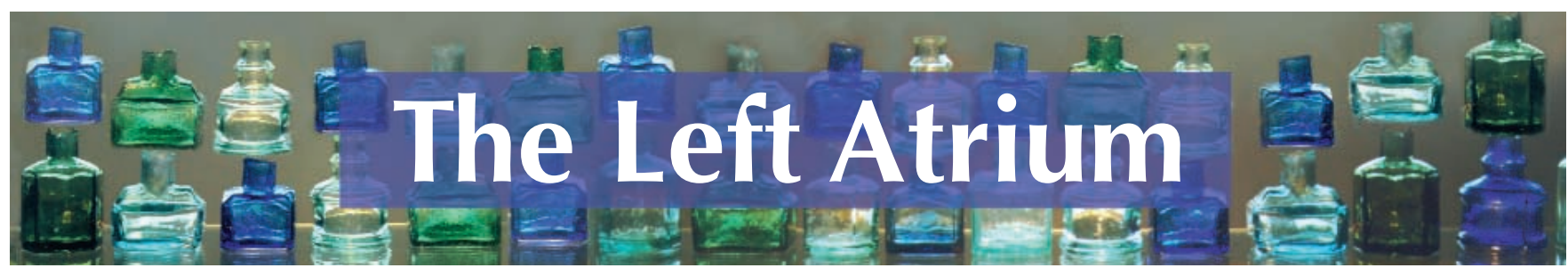

\section{Prescribing errors}

Powerful medicines: the benefits, risks, and costs of prescription drugs

Jerry Avorn

New York: Alfred A. Knopf; 2004

448 pp \$39.95 (cloth) ISBN 0-375-41483-5

$\mathrm{T}$ here are many jobs that I would not want to have, and these days being an executive in the pharmaceutical industry probably tops the list. The year 2004 was an annus horribilis for the drug companies. GlaxoSmithKline was revealed as having suppressed unfavourable research findings on the use of paroxetine (Paxil) in the treatment of pediatric depression. Merck was hammered over allegations that it kept rofecoxib (Vioxx) on the market long after it knew that the product increases the risk of death from cardiovascular events. Since 1997, approval ratings for the pharmaceutical industry in the United States have gone from $80 \%$ to just over $40 \%$, and the industry is now flirting with levels enjoyed by oil and tobacco companies.

Now along comes Jerry Avorn's new book, Powerful medicines: the benefits, risks, and costs of prescription drugs. It is not going to make life any easier for the harried drug companies.

Avorn is a well-known and highly published internist and geriatrician working out of Harvard University and Brigham and Women's Hospital in Boston. One of his first efforts in pharmaceutical policy research from the early 1980s showed that physicians are unknowingly influenced by promotional efforts from the pharmaceutical industry and, as a result of that influence, adopt suboptimal prescribing practices. This paper was a pioneering effort and is still frequently cited.

Avorn is not afraid to confront shibboleths. His view that the marketplace, rather than science and altruism, is the prime force for developing and evaluating new drugs is clear when he says that " $[W]$ e have begun to allow the marketplace to usurp the place of evidence in determining which treatments are effective." He backs up this assertion when he describes how the oral hypoglycemic agent troglitazone (Rezulin) was allowed to stay on the American market for a couple of years after it was pulled from the shelves in the United Kingdom. While people using the drug were experiencing severe and sometimes fatal liver damage, Parke-Davis, the company marketing the drug in the US, was running further clinical trials. When one company scientist wondered if study physicians should be informed of the death of a study participant, the response he got was that there was "NO REGULATORY OBLIGATION to send a letter to the [study] physicians"' (emphasis in original letter).

Nor does the US Food and Drug Administration escape Avorn's scrutiny. In the Rezulin story he quotes from a letter an FDA regulator sent to Congressman Henry Waxman: "I have been frustrated in my efforts to convince [FDA] management that the time has come to remove Rezulin from the market." He also chides the FDA for the erosion of its previously strict standards over accuracy in drug advertising. In 1997 the FDA removed most of the prohibitions on direct-to-consumer television advertising. The result has been a flood of advertising that Avorn believes is helping to make the health care system into just another marketplace where commercial forces can run free.

Although the subject of Avorn's book is serious, his tone is often humorous. The hue and cry about the safety of Canadian drugs that was raised by the pharmaceutical companies and the FDA, among others, becomes the "Maple Peril" for which Avorn notes there is scant, if any, scientific evidence. (What goes on in Canada is largely absent from Avorn's account, although the reimportation of drugs from Canada to the United States is given a few pages.) Another example of his wit occurs in his discussion of the problems of making decisions about the utility of drugs; "premature extrapolation" of data, Avorn suggests, is the most common "dysfunction" in pharmacoeconomics, a problem that is "hard to talk about openly because its outcome is so unsatisfying and embarrassing for everyone involved."

The issue of the affordability of medications

$a$ in the United States is a theme that runs through this book. Avorn and his colleague at Harvard, Steve

Soumerai, were responsible for showing that, when New Hampshire put a cap on the monthly number of prescriptions that welfare recipients would get for free, the result was an increase in nursing home admissions that probably cost the state government as much as it saved on drug costs. Avorn returns to the question of costs when he discusses the recently passed drug benefit that was added to Medicare (publicly funded health insurance for Americans aged 65 and over). The law expressly forbids the 
government from negotiating prices with the drug companies. In addition, it totally ignores the need to improve the cost-effectiveness of prescribing. Avorn concludes that, far from containing overall drug costs, this law is destined to keep them rising so that drugs become even more unaffordable.

Ensuring that all Americans have adequate drug coverage will not be easy, given the increasing privatization of US medicine that has been going on for the past two decades and the political clout of the people and institutions that have been pushing for privatiza- tion. Ideally, Avorn would like all health care delivery organizations to be run on a nonprofit basis, but he is pragmatic enough to recognize that this goal is unattainable in the present political climate. Instead, he calls for legislation to make all insurers offer a comprehensive formulary of medications in all categories - but with the caveat that they could choose which drugs in each class to cover, depending on what kind of discounts they negotiate with drug manufacturers. Unfortunately, even this modest step seems wildly optimistic.
Every generation or so, something comes along to radically change the direction of the pharmaceutical industry and everything associated with it. Today we may be at one of those cusps of change. If we are, Avorn's book will be one of those things that help to propel us into a better future.

\section{Joel Lexchin}

Dr. Lexchin teaches health policy at York University and is an emergency physician at the University Health Network, Toronto, Ont.

\section{Room for a view}

\section{The leaving game}

T $t$ was going to happen sooner or 1 later, and now, finally, it had come. Time to pack up. Everyone leaves eventually, going to new places, making new friends, shaking off the dust from the past. Then it happens to you, too. Want it or not, you leave, and hopefully you leave something behind to come back to.

It was the inevitably paced ticking of the clock that made my parents realize two things. First, I would actually graduate from medical school and not flip pancakes for a living (also an allnight job, as my mother pointed out the day I wanted to drop out). Second, although I was already living away from home, graduation would mean that I would move even further away. No more weekend visits. No more discussing the same evening paper on the provincial anytime phone bundle.

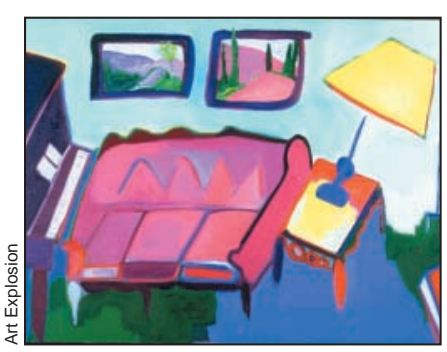

"Farrah, my princess, you are my biggest investment. I want you to promise me that you will never, never go to Africa. I don't want you running off - they have different diseases there and you wouldn't be immune."

As an only child, I have become jaded. I ignore such melodrama; instead, I get caught up with the subtleties.

"Did you say biggest, or best, investment?" I asked.

"Well, definitely my biggest. Do you know how much it costs to raise a child in Bangladesh?"

"Could you say something useful?" "No. Pretty useless."

Exasperated, I stood up to leave the table. As I was walking away, I heard my mother practically wailing, but pausing long enough to throw her napkin at my father. "Don't be a loser, Abdul, and eat those At what began as a surprisingly normal family meal, my mother burst into irreconcilable tears upon the mention of residency. My father, usually oblivious to the reason for such outbursts, came up with his own recommendations. peas. I made them especially for you.”

It hardly matters that my mother married my father when she was my age or that my father left home for school at the age of 15 , halfway across the world, without looking back.
$I$ must send postcards from my electives and say, "No, Mom, you may not embroider my lab coat. It makes me feel like a geek."

I called my grandfather, whose patriarchal irrationality has always been strangely refreshing. His voice has softened from more than twenty years with Parkinson's disease, but his attitudes remain firmly in the wartime era. At 83, he tells me that if he were my age again, he would sell weed; as a survivor, he cares little about what the family thinks of his ideas.

"Put them in a home," he said matter-of-factly, as though the answer was astoundingly obvious. $\mathrm{He}$ added: "I, however, refuse to enter a seniors' home. I would rather be dead. Remember that and remind your parents."

My grandmother has bought me a new flannel nightie for residency. And so, I am left, despite overwhelmingly good intentions, to my own devices.

Sometimes, though, I get help within the hospital milieu. I have received ample, unsolicited advice on marriage, waffle-making, cruise ships and even lottery tickets from my patients, while my professors, likely in hypomanic episodes, have further suggested that I travel far away and see 